U.S. Department of the Interior

U.S. Geological Survey

Fact Sheet 218-95

\title{
BOREHOLE GEOPHYSICAL LOGGING FOR WATER-RESOURCES INVESTIGATIONS IN PENNSYLVANIA
}

bution, vertical borehole flow, and water-yielding capabilities.

\section{Why Log A Well?}

Well logging is a relatively inexpensive method of collecting subsurface hydrogeologic data that might otherwise be unknown. Examples of standard log information are total well depth, depth to water level (deep levels), casing length, fracture disformation geology, fracture distrigeologic formations penetrated by a well by raising and lowering a set of probes or sondes that contain water-tight instruments in the well (fig. 1). The data collected can be used to determine general

\section{What is Borehole}

Borehole geophysical logging is a procedure to collect and transmit specific information about the

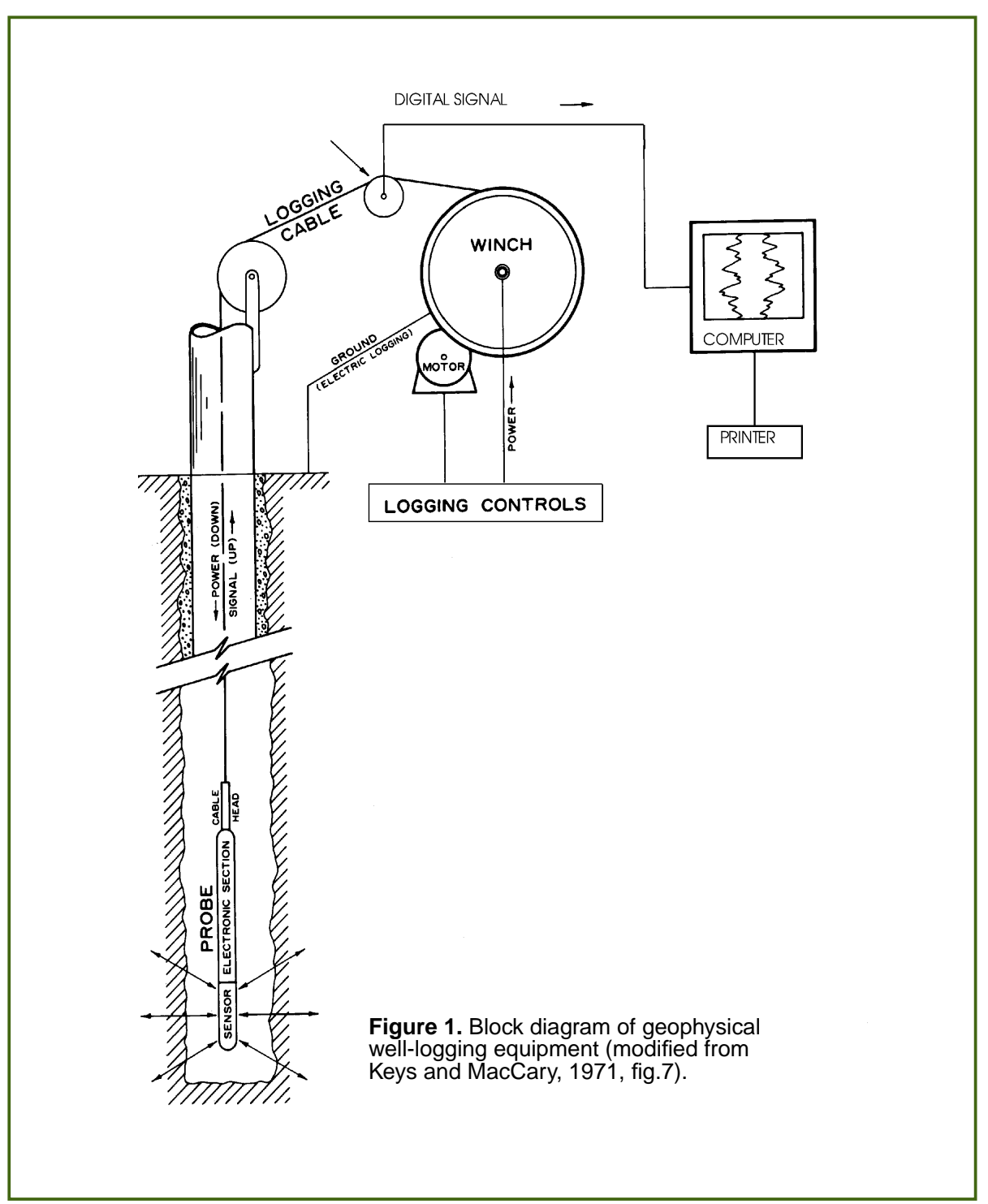

tribution, general formation geology, water-producing and receiving zones, and zones of flow within the borehole. This information is usually sparse or missing and is necessary for most groundwater investigations.

\section{How Do Well Logs Provide Useful Information?}

Borehole geophysical logs supplement the well driller's notes, which are usually inconsistent from site to site. Typical drilling notes also are sketchy and usually vary by individual. Formation rock cuttings produced during drilling may be misidentified or improperly collected, and existing well information may not include critical information, such as locations of water-producing zones.

Well logs can supply or fill in missing data, such as-

- general well construction

- general formation geology

- water-producing zones

- water-receiving zones

- zones of vertical borehole flow

- measurement of vertical borehole flow

- views of the borehole by television camera

\section{What Types of Geophysical Logs Are Collected by the U.S. Geological Survey in Pennsylvania?}

\section{Logs used to correlate geologic formations}

\section{The Natural-Gamma Log}

The natural-gamma or gamma $\log$ measures the natural-gamma radiation (photons) emitted by all 
rocks. The most common emitters of gamma radiation are uranium-238, thorium-232, and their daughter elements, and potassium-40. These radioactive elements are concentrated in clays by adsorption, precipitation, and ion exchange. Fine-grained sediments such as shale or siltstone usually emit more gamma radiation than sandstone, limestone, or dolomite. The gamma log can be run in cased or uncased holes and in or out of water. However, casing reduces the magnitude of the gamma response. The gamma log is used primarily to correlate geologic units between wells.

\section{Logs used to identify fractures}

\section{The Caliper Log}

The caliper $\log$ is a continuous record of well diameter, usually recorded in inches. Changes may be related to the size and location of fractures, the bottom of casing, drilling technique, or lithology. The caliper log is used to identify possible water-bearing fractures and to adjust responses of other logs to changes in well diameter.

\section{The Single-Point-Resistance Log}

The single-point-resistance log records the electrical resistance of a formation between the probe in a water-filled well below the bottom of the casing and an electrical ground at land surface. Generally, electrical resistance increases with formation grain size and decreases with borehole diameter, water-bearing fractures, and increasing dissolved-solids concentration of the well water. The single-point-resistance log is used primarily to correlate geology between wells and to help iden- tify formation water-bearing zones.

\section{Logs used to identify water- bearing, water-receiving, and borehole-flow zones}

\section{The Fluid-Resistivity Log}

Fluid resistivity is the inverse of fluid conductivity. The fluidresistivity log measures the electrical resistivity of the water column in the well. The fluidresistivity probe measures the resistivity of borehole water between electrodes in the probe. Fluid-resistivity logs reflect changes in the dissolved-solids concentration of the well water. Fluid-resistivity logs are used to identify water-producing and water-receiving zones and to determine intervals of vertical borehole flow. Water-producing and water-receiving zones are usually identified by distinct changes in resistivity. Intervals of vertical borehole flow are usually identified by a low-resistivity gradient between a water-producing and a water-receiving zone. Also, zones of salt water intrusion and some types of contaminant plumes can be identified.

\section{The Fluid-Temperature Log}

Fluid-temperature logs provide a continuous record of vertical variations in the water temperature in a well. Temperature logs are used to identify water-producing and waterreceiving zones and to determine zones of vertical borehole flow. Intervals of vertical borehole flow are characterized by little or no vertical temperature gradient.

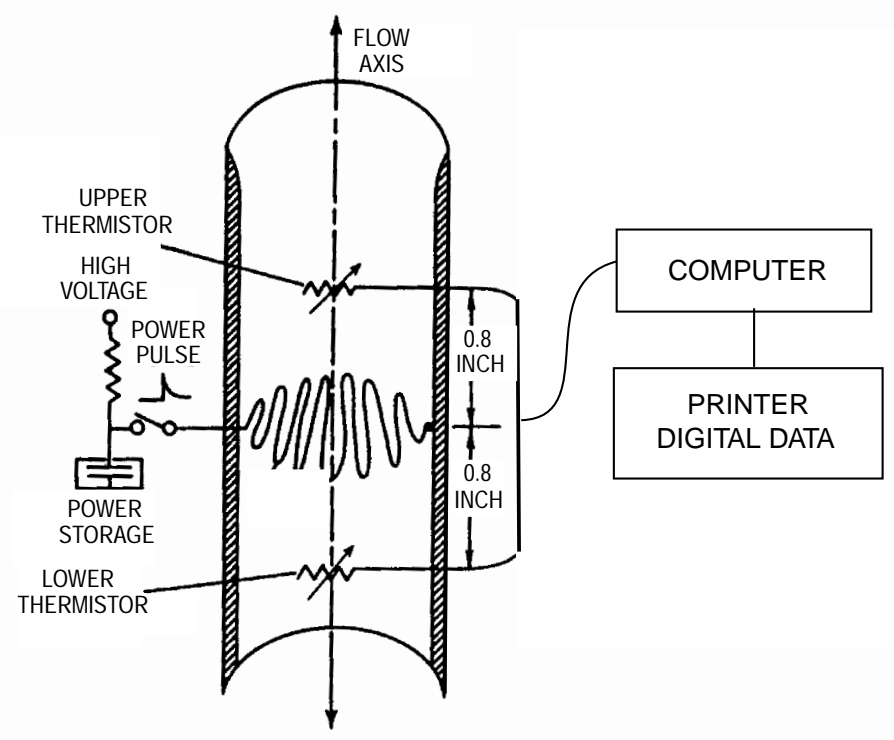

Figure 2. Heat-pulse flowmeter equipment (modified from Hess, 1982, fig. 90). 


\section{Logs used to measure vertical borehole flow}

\section{The Heat-Pulse Flowmeter Log}

The direction and rate of vertical borehole flow can be determined by the use of the heatpulse flowmeter. The heat-pulse flowmeter operates by slightly heating a thin interval of water between two sensitive thermistors (heat sensors) as shown in figure 2. A measurement of direction and rate is computed when a peak temperature is recorded by one of the thermistors. The range of flow measurement is about 0.01 to
1.0 gallons per minute in a $2-$ to 8-inch diameter well.

\section{Brine-Tracing}

If the direction and rate of borehole flow exceeds 1 gallon per minute in a 2- to 8-inch diameter well, a slug of high-conductance fluid can be injected (fig. 3) and traced in the suspected zone of flow. The movement of the slug can be monitored by use of the fluid-resistivity probe (fig. 4). This is known as the "brine-tracing" method of flow measurement. The lower limit of flow measure-

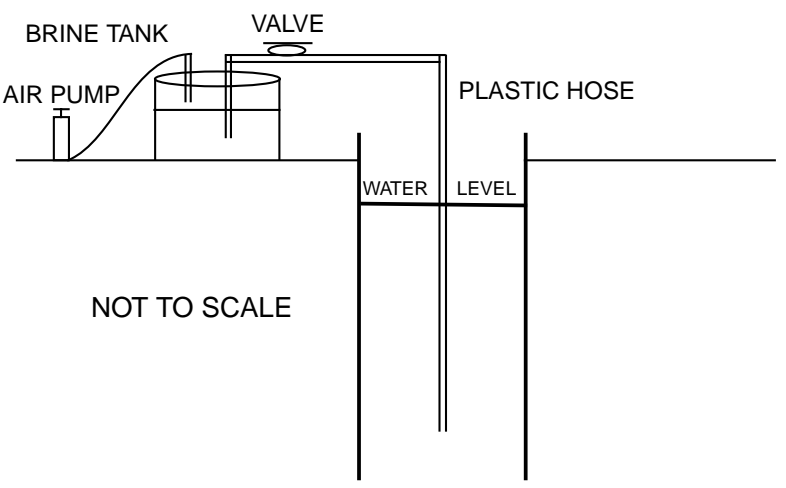

Figure 3. Diagram of brine-injection setup (modified from Pattern and Bennett, 1962, fig. 1).

ment is about 0.5 gallon per minute in a 6-inch diameter borehole.

\section{Log used to visually inspect a well}

\section{Down-Hole Television Camera}

This is a separate logging system that has its own winch and power supply and is available to the Pennsylvania District. The television camera allows visual inspection of cased or open holes with a minimum 2-inch diameter. A color monitor displays a live down-hole video picture. A video recorder records the image in standard VHS format. This is an excellent tool to view casing, well screen, lithology, and fractures that intersect a well.

\section{How Are Well-Log Data Stored?}

Analog (paper copy) and digital well-log data for the Commonwealth of Pennsylvania are stored at the USGS office in Lemoyne, Pa. Analog well-log data are available for most wells logged in Pennsylvania from 1948 to present. Digital well-log data are available on most wells

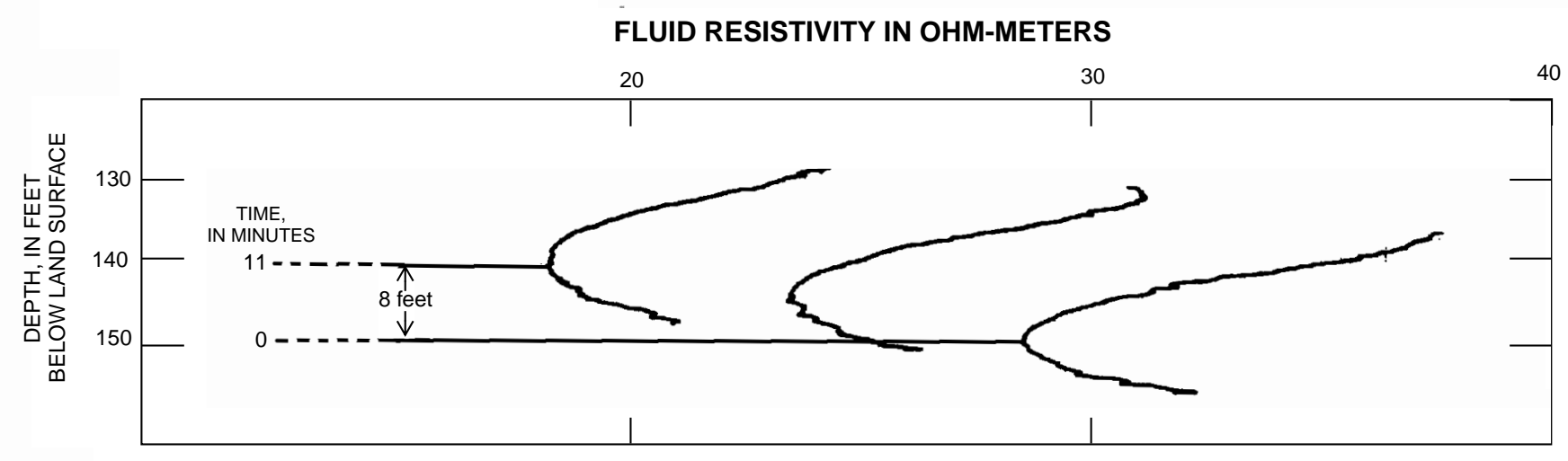

Figure 4. Upward movement of a brine slug injected at 150 feet below land surface. 

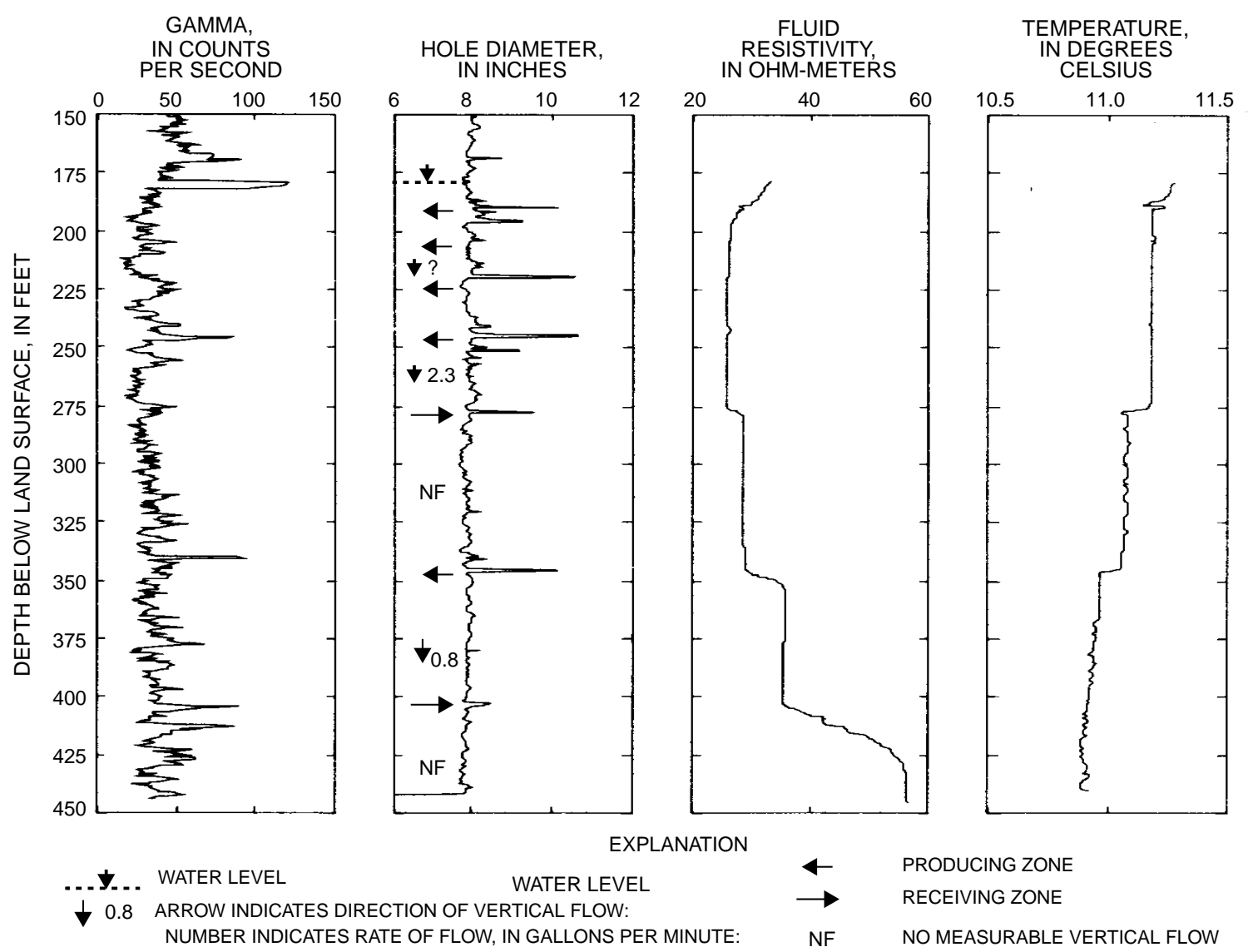

ARROW INDICA QUESTION MARK (?) INDICATES RATE NOT DETERMINED

EPLANATION

Figure 5. Typical suite of geophysical logs. Caliper log shows water-producing, vertical borehole flow, and water-receiving zones (from Williams and Conger, 1990, fig. 3).

logged from 1987 to present. The digital data are available in ASCII (text) format.

\section{Summary}

Geophysical well logging is an efficient method of acquiring subsurface hydrogeologic data. Well$\log$ information such as total well depth, casing length, fracture distribution, general formation geology, locations of water-producing and water-receiving zones, and location intervals of borehole flow usually can be identified, if present. A suite of typical well logs is shown in figure 5 . Vertical flow rates were determined by the brine-trace method. Water- production, vertical-flow and water-receiving zones are indicated on the caliper log.

\section{References Cited}

Hess, A.E., 1982, A heat-pulse flowmeter for measuring low velocities in boreholes: U.S. Geological Survey Open-File Report 82-699, 44 p.

Keys, W.S., and MacCary, L.M.,1971, Application of borehole geophysics to water-resources investigations:

U.S. Geological Survey Techniques of Water-Resources Investigations, book 2, chap. E1, p. $8-12,19,22,30-36,64-66$.

Patten, E.P., and Bennett, G.D., 1962, Methods of flow measurements in well bores: U.S. Geological Survey Water-Supply Paper 1544-C, p. 4-6.

Williams, J.H., and Conger, R.W., 1990, Preliminary delineation of contaminated water-bearing fractures intersected by openhole bedrock wells: Ground Water Monitoring Review, Fall 1990, p. 118-121.

Randall W. Conger-1996

For more information please contact:

District Chief

U.S. Geological Survey, WRD

840 Market Street

Lemoyne, PA 17043-1586

(717) 730-6900 